\title{
The Effect of Scientific Inquiry Learning Model Using Macromedia Flash on Student's Concept Understanding and Science Process Skills in Senior High School
}

\author{
Rohana Hutahaean ${ }^{1}$; Mara Bangun Harahap ${ }^{2}$ : Derlina $^{3}$ \\ ${ }^{1}$ (Post Graduate, State University of Medan, Medan, Indonesia) \\ ${ }^{1}$ Rohanahutahaean@gmail.com \\ ${ }^{2}$ (Lecturer, State University of Medan, Medan, Indonesia) \\ ${ }^{3}$ (Lecturer, State University of Medan, Medan, Indonesia), \\ Corresponding Author: Rohana Hutahaean ${ }^{l}$
}

\begin{abstract}
This study aimed to analyze the effect of scientific inquiry learning model using macromedia flash on understanding the concept and science process skills of high school students. This research is a quasi experimental research with two group pretest posttest design. The population of this research is all students of class X Senior High School Advent Air Bersih Medan. Selection of sample is done by cluster random sampling that is X-1 as experiment class applied scientific learning model inquiry using macromedia flash and X-3 as control class applied conventional learning. Instrument used in this research is instrument of concept comprehension in essay form as much as seven problem and instrument of science process skils in form of student worksheet which have been declared valid by expert team. From the results of the study concluded that the understanding of the concept of students applying scientific inquiry learning model using macromedia flash better than the students 'concept understanding with conventional learning and science process skills students who apply scientific inquiry learning model using macromedia flash better than students' science process skills with conventional learning .
\end{abstract}

Keywords: Scientific inquiry learning model, Macromedia flash, Concept Understanding, Science process skills

\section{Introduction}

The growing community environment and demanding society to equip themselves to compete, in this case education has an important role in all areas of life to produce quality human resources. One of the government policies in improving the quality of human resources in the country of Indonesia is to improve the education curriculum Indonesia. In 2013 the 2013 curriculum begins with characteristics not only prioritizing knowledge alone, but the attitudes and skills in its implementation using a scientific approach. A scientific approach is used in the 2013 curriculum that emphasizes the modern pedagogic dimension of learning. The 2013 curriculum orientation is an increase and balance between attitude competence, skill and knowledge. The scientific appoach in such learning involves observing, asking, trying, processing, presenting, summarizing, and creating for all subjects. The learning process in the 2013 curriculum is implemented using a scientific approach. In the application of the scientific approach to learning in the classroom there are five stages namely: observing, asking, collecting data, reasoning and communicating. In the learning activities with scientific approach is very supportive to improve students' science process skills. With the steps of existing learning activities, it is expected that the science process skills of the students will be trained because they provide direct experience in learning and gathering information. The field of technology must be supported by science science field which one of them is physics. Natural Sciences is formed and evolved through a scientific process, which must be developed in learners as meaningful experiences that can be used as a stock for further development. The nature of science includes products, processes, and scientific attitudes. [1] describes the relationship between the environment and the learning process as an illustration in the comparison of evaluation and application of learning and as an observation in the assessment of learning outcomes.

Physics is one branch of Natural Sciences that underlies technology and the concept of living in harmony with nature. Physics as part of science has a big role in technological development. This means that the learning of physics is an integral part of the development of science and technology. Physics learning must receive serious and serious attention, if it wants rapid scientific and technological development. One way that 
can be taken in improving the quality of physics learning is to consider the use of appropriate methods in the delivery of each concept, so that students easily gain an understanding of the concept of physics. Understanding the concepts and principles of physics is a prerequisite for the success of physics study to proceed to a higher level that can be applied in daily life. Understanding the concepts and principles of physics will certainly be obtained through learning activities. Based on the impact of these competencies, understanding is a very fundamental element. This ability is generally emphasized in the learning process. Students are required to understand or understand something that is learned, to know something that is being communicated and can utilize its contents. Understanding the concept is constructing the meaning of learning materials, including what is spoken, written and described by the teacher [2].

[3] Said that learning is a component of the science of education with respect to the purpose and reference materials of interaction, both implicit and explicit. Learning is a series of activities towards the development of the whole human person, concerning the elements of creativity, taste and desire, cognitive, affective and psikomotorik. Physics learning basically, a process directed at a natural phenomenon that occurs, by way of knowing about nature in a systematic, So that science is not only the mastery of a collection of knowledge in the form of facts, concepts, and principles but also an invention. One of the most effective physics learning activities that truly reflects the nature of physics is practice. Practical activity is the performance shown by teacher or student in the form of demonstration or by student experiment which take place in laboratory through experiment and project. Practice activities play an important role in physics learning because practice provides opportunities for students to be creative in doing science process skills. Scientific process skills are a skill that can be developed by using_practice [4]

But in fact based on interviews with physics teacher college who served in senior high school Advent Air Bersih Medan in the academic year 2016/2017 odd semester, that physics learning in the school tends to use conventional learning so that students only emphasized on the aspects of memorizing the physics formula and working on problems -question. This shows that the understanding of the concept of physics in students is still lacking. The same is true that in senior high school Advent Air Bersih Medan, students rarely carry out the lab because the laboratory equipment is not complete, so it can hinder the students' science process skills. The learning process without going through the experiments in advance to make students feel bored and tired during the lesson. This resulted in the students' process skills becoming passive and less formed.

The alternative that is used to improve the science process skill and conceptualizing is by applying the scientific inquiry learning model. The scientific inquiry learning model used in classroom learning, is very supportive for improving the science process skills in physics learning. [5] Concluded Scientific inquiry helps students develop science process skills and enable students to think and develop knowledge such as scientists / scientists. Physics learning is concerned with how to find out about nature in a systematic way, so that physics learning is not just a mastery of a collection of knowledge. The scientific inquiry learning model is a learning model that involves students in truly original research problems by confronting students in the field of investigation, helping to identify conceptual or methodological problems.

According to [6];[7]; [8] On the results of his research indicates that the model of scientific inquiry teaching improves the skills of students' science processes so that there are differences in student learning outcomes by using conventional learning model. [9] Concluded that scientific inquiry learning is better than traditional pursuits for physics lessons. According to [10] that on the results penelitinnya inquiry-based learning model can improve the understanding of the concept of physics. According to [11] that inquiry learning models not only scaffold students' understanding of science, but also their ability to understand and use multimodal representations and to produce better explanatory qualities. In addition, an inquiry-based learning approach can improve teacher competence in learning activities. After being given an inquiry study it can also develop students' good behaviors associated with changing understanding of physics concepts, increasing values that meet the minimum mastery criteria, always active, passionate in learning and communicative.

In addition to understanding the concept and skills of the science process that supports the scientific inquiry learning model, the use of simulation media can also support the scientific inquiry learning model in the learning process that can facilitate students in raising the spirit and motivation of students in doing a pratikum. One technology that can support the learning process is the simulation media. [12] suggests that the use of learning media in teaching and learning can (1) generate new desires and interests, (2) generate motivation and stimulation of learning activities, and (3) bring psychological influences on students. The use of learning media at the learning orientation stage will greatly help the effectiveness of the learning process and delivery of messages and learning missions. Media is one of the critical success factors of learning.

Scientific inquiry teaching can be helped by using instructional media such as video tutorial, flash animation and others so as to facilitate the teacher in conveying information to the students. Where the scientific inquiry model using macromedia flash is student-centered learning that works in groups (called learning in teams), which uses macromedia flash application program that makes student interest in learning. 
Through the media learning process can be more interesting and fun (joyfull learning), for example students who have an interest in color then it can be given media with an attractive color. Likewise, the student who likes to be creative always wants to create the shape or object he wants, the student can be given the appropriate media [13]. According [14] concluded that learning with macromedia flash can increase students' interest and understanding in physics learning.

\subsection{Model of scientific inquiry study}

The scientific inquiry learning model is designed to bring students directly into the inquiry process. Through scientific inquiry model the student is expected to actively ask the question why something happened then search and collect and process the data to determine the answer of the question. The application of scientific inquiry instructional model in teaching and learning activities aims to develop a deeper understanding of science concepts and shape students' scientific knowledge. Through experimental activities students can try various ways to complete experiments conducted so as to develop the ability to think it has. Students are expected to be responsible for conducting investigations in identifying problems, hypotheses, designing methods to prove hypotheses, analyzing them and making final conclusions. The scientific inquiry learning model is a learning model that involves students in truly original research problems by confronting students in the field of investigation, helping to identify conceptual or methodological problems. The phases in this model are (1) the students presented a field of research, (2) the students make the problem, (3) the students identify problems in the study, (4) the students speculate to clarify the problem [15].

The nature of the scientific inquiry approach is to teach students to process information with techniques once used by biological researchers, for example, identifying problems and using methods to solve the problem. The following explanation of the syntax of scientific inquiry learning model according to [15] are: 1) In the first stage students presented the field of research, which includes the methodologies used in the study. 2) In the second stage, the problem begins to be organized so that the student can identify the problem in the research. 3) In the third stage, students are asked to speculate about the problem, so that students can identify the difficulties involved in the research. 4) In stage four, students are asked to speculate on ways to clarify the difficulty, by designing Re-test, process data in different ways, generate data, develop constructs and so on. Teacher's job is to guide, train, and educate research by emphasizing the research process and persuading students to reflect on the process. Teachers should be careful that identifying facts is not the main issue that should be emphasized in research. Furthermore, the most important thing in this regard is how teachers can encourage students to deal with complex and well-researched research questions.

Teacher's job is to guide, train, and educate research by emphasizing the research process and persuading students to reflect on the process. Teachers should be careful that identifying facts is not the main issue that should be emphasized in research. Furthermore, the most important thing in this regard is how teachers can encourage students to deal with complex and well-researched research questions.

\subsection{Concept understanding}

According to [2] is understanding which means constructing the meaning of learning messages, whether oral, written, or graphic that is delivered in learning, books or computer screens. The cognitive processes in the categories of understanding include 1) Interpreting, occurring when students can change information from one form to another. Interpreting is the conversion of words into other words, images into words, words into pictures, numbers into words, words into numbers and the like. The other names are translating and clarifying. 2) Exemplifying, occurs when students give examples of general concepts or principles. Exemplifying involves the process of identifying the essential features of general concepts and principles. Other names to illustrate are illustrating and modeling. 3) Classifying, occurs when students know that something (for example, an example) falls into a specific category (eg concept or principle). Classifying involves the process of detecting traits or patterns corresponding to those examples and concepts or principles. Classifying is a cognitive process that complements the process of modeling. Other names of classifying are categorizing or grouping. 4) Summarizing, occurs when students put forward a sentence that delivers the information received or refers to a theme. The other names of the summarize are generalizing and abstracting. 5) Inferring, including the process of finding patterns in a number of examples. Summing up occurs when the student can make a logical conclusion of the information received. Other names of the summarize are extracting, extrapolating, interpolating, and predicting. 6) Comparing, occurs when students are able to determine the relationship between two ideas, two objects, and the like. Other names of the summarize are contrast, match, and map. 7) Explaining, occurs when students are able to create causal models in a system. Another name for explaining is modeling.

\subsection{Science process skills}


The science process skills is a complex capability device commonly used in conducting scientific inquiry into a series of learning process [4]. Science process skills in this study refers to [4] are as follows 1) obseving, 2) asking question, 3) Formulate hypotheses, 4) Find patterns and variable relationships, 5) Communicate effectively, 6) Designing an experiments,7) conducting an experiments ,8) Make a conclusion.

\section{Method}

\subsection{Population and sample}

Population is the goal that becomes the object of research. [16] explains that the population refers to all members of a particular group that generalizes. Population in this research is all class X High School Private Advent Air Bersih Medan. Sampling by cluster random class where each class (random class) has the same opportunity to be sampled in the study. The sample is divided into two classes namely class X-1 as experimental class that is learned by using scientific inquiry learning model using macromedia flash and class X-3 as control class which is learned by using conventional learning .

\subsection{Data collection techniques}

This type of research is a quasi experimental research is research that aims to determine the effect of something imposed on the subject of the student. The study involved two different sample classes treated. The experimental class is treated in the form of learning using scientific inquiry instruction model using macromedia flash. Control class is treated in the form of learning using conventional learning. The variables of this study consist of two types of independent variables and dependent variables. The independent variable is the variable that affects the dependent variable. The independent variable in this research is scientific inquiry instruction model using macromedia flash. The dependent variable is the variable that is influenced or the result is due to the independent variable. The dependent variables in this research are 1) understanding the concept which consists of seven indicators that is interpreting, modeling, classifying, summarizing, summing up, comparing, explaining. 2) Scientific process skills consisting often indicators, observation, asking questions, formulating hypotheses, predicting, finding patterns and variable relationships, communicating effectively, designing experiments, conducting experiments, manipulating effective materials and tools, measuring and calculate.

The study involved two different treatment classes. To find out the student learning outcomes done by giving tests on both classes before and after being treated. The experimental design of quasi experiments was design: two group pretest -postest design. Thus the design of this study is listed in Table 1.

Table 1. Research design

\begin{tabular}{|c|c|c|c|}
\hline Class & Pretest & Treatment & Posttest \\
\hline Experiment & $\mathrm{Y}_{1}$ & $\mathrm{X}_{1}$ & $\mathrm{Y}_{2}$ \\
\hline Control & $\mathrm{Y}_{1}$ & $\mathrm{X}_{2}$ & $\mathrm{Y}_{2}$ \\
\hline
\end{tabular}

Information :

$\mathrm{X} 1$ : Learning using scientific inquiry learning model using macromedia flash on temperature and heat material.

$\mathrm{X} 2$ : Learning by using conventional learning on temperature and heat materials.

Y1: Pretest given prior to treatment in the experimental class and control class.

Y2: Postes given after treatment in the experimental class and control class.

Data collection in this research by using research instrument, that is comprehension concept test and student process science skill. Instrument of concept comprehension in the form of test essay as much as 7 problem and test of science process skill in form of practice test in form of student worksheet.

Before the test is used, first reviewed the validity of its content through the opinions of experts as a validator. Content validity refers to an instrument that has the conformity of contents in exposing / measuring to be measured [17] In addition, content validation is also intended for the content of the test tested in accordance with the contents of the current curriculum. Validation of this content is determined by expert judgment, to give an idea of the validity of the test before it is followed up. The concept comprehension test and science process skill test is validated by the lecturer of Physics Education Graduate of Medan State University, as a panel of experts in determining the suitability of the test indicators. After the process of revision and improvement of the suggestions provided by the expert, it is concluded that the test has been able to be used to determine the level of understanding the concept and skills of the science process.

Data collection is done in two stages, the first step is collecting data about students 'concept understanding and second stage collecting data about students' science process skill. Data obtained in the study were analyzed descriptively and inferentially. Descriptive analysis aims to describe the understanding of concept and skill of science process. Inferential analysis to test the research hypothesis was done by t-test, before the test-t first tested normality and homogeneity test with the help of SPSS 17 software. 


\section{Results}

Table 2. Summary of pretest - posttest understanding the concept and science process skills of control class and experimental class

\begin{tabular}{|l|l|l|l|l|l|}
\hline $\begin{array}{l}\text { Dependent } \\
\text { variable }\end{array}$ & Class & Mean Pretest & $\begin{array}{l}\text { Standard } \\
\text { deviation }\end{array}$ & Mean Postest & $\begin{array}{l}\text { Standard } \\
\text { deviation }\end{array}$ \\
\hline $\begin{array}{l}\text { Understanding } \\
\text { the concept }\end{array}$ & Control & 4,86 & 1,89 & 72 & 51,049 \\
\cline { 2 - 6 } & Experiment & 4,99 & 2,08 & 77,9 & 38,01 \\
\hline $\begin{array}{l}\text { science process } \\
\text { skills }\end{array}$ & Control & 22,31 & 5,125 & 70,52 & 3,55 \\
\cline { 2 - 6 } & Experiment & 23,08 & 5,302 & 79,07 & 3,81 \\
\hline
\end{tabular}

\begin{tabular}{|c|c|c|c|c|c|}
\hline $\begin{array}{c}\text { Dependent } \\
\text { variable }\end{array}$ & Class & $\begin{array}{c}\text { Mean } \\
\text { Pretest }\end{array}$ & $\begin{array}{c}\text { Standard } \\
\text { deviation }\end{array}$ & $\begin{array}{c}\text { Mean } \\
\text { Postest }\end{array}$ & $\begin{array}{c}\text { Standard } \\
\text { deviation }\end{array}$ \\
\hline \multirow{2}{*}{$\begin{array}{c}\text { Understanding } \\
\text { the concept }\end{array}$} & Control & 4,86 & 1,89 & 72 & 51,049 \\
\cline { 2 - 6 } & Experiment & 4,99 & 2,08 & 77,9 & 38,01 \\
\hline \multirow{2}{*}{$\begin{array}{c}\text { science } \\
\text { process skills }\end{array}$} & Control & 22,31 & 5,125 & 70,52 & 3,55 \\
\cline { 2 - 6 } & Experiment & 23,08 & 5,302 & 79,07 & 3,81 \\
\hline
\end{tabular}

Table 3. Test-t Post test understanding of concepts

\begin{tabular}{|c|c|c|c|c|}
\hline Post test Equation Test & $\mathbf{t}_{\text {counted }}$ & $\mathbf{t}_{\text {table }}$ & Sig & Information \\
\hline Test- $t$ & 3,28 & 2,00 & 0,62 & Significantly different \\
\hline
\end{tabular}

Based on Table 3, this result indicates that $\mathbf{t}_{\text {count }}>t_{\text {table }}$ and significance value greater than 0.05 . Based on these results it can be concluded that there is a difference understanding of the concepts of students in classes that are taught by conventional learning and classes that with scientific inquiry model using macromedia flash, with the results obtained understanding the concept of classroom students with scientific inquiry model using macromedia flash better than the class with conventional learning.

Table 4. Test-t Post test the skills of the science process

\begin{tabular}{|c|c|c|c|c|}
\hline Post test Equation Test & $\mathbf{t}_{\text {counted }}$ & $\mathbf{t}_{\text {table }}$ & Sig & Information \\
\hline Test $-\mathrm{t}$ & 4 & 1,67 & 0,07 & Significantly different \\
\hline
\end{tabular}

Based on Table 4, this result indicates that $\mathrm{t}_{\text {count }}>\mathrm{t}$ table and significance value greater than 0.05 . Based on these results it can be concluded that there are differences in the skills of students in the classroom science process that dibelajarkan with conventional learning and classes that with scientific inquiry model using macromedia flash, with the results obtained science classroom skills with scientific inquiry model using macromedia flash better than Class with conventional learning.

Table 5. Analysis of conceptual understanding indicators

\begin{tabular}{|l|l|l|l|l|l|l|l|}
\hline \multirow{2}{*}{ Model } & \multicolumn{6}{|l|}{ Indicator } \\
\cline { 2 - 8 } & $\mathbf{1}$ & $\mathbf{2}$ & $\mathbf{3}$ & $\mathbf{4}$ & $\mathbf{5}$ & $\mathbf{6}$ & $\mathbf{7}$ \\
\hline $\begin{array}{l}\text { Scientific } \\
\text { inquiry using } \\
\text { macromedia } \\
\text { flash }\end{array}$ & $89,6 \%$ & $85,7 \%$ & $89 \%$ & $87 \%$ & $73 \%$ & $98,6 \%$ & $98 \%$ \\
\hline $\begin{array}{l}\text { Conventional } \\
\text { learning }\end{array}$ & $79 \%$ & $82 \%$ & $79 \%$ & $80 \%$ & $71 \%$ & $84 \%$ & $83 \%$ \\
\hline
\end{tabular}

In summary, the analysis of indicators of students' concept of control class with conventional learning and experimental class with scientific inquiry model using macromedia flash can be seen in Figure 1. 


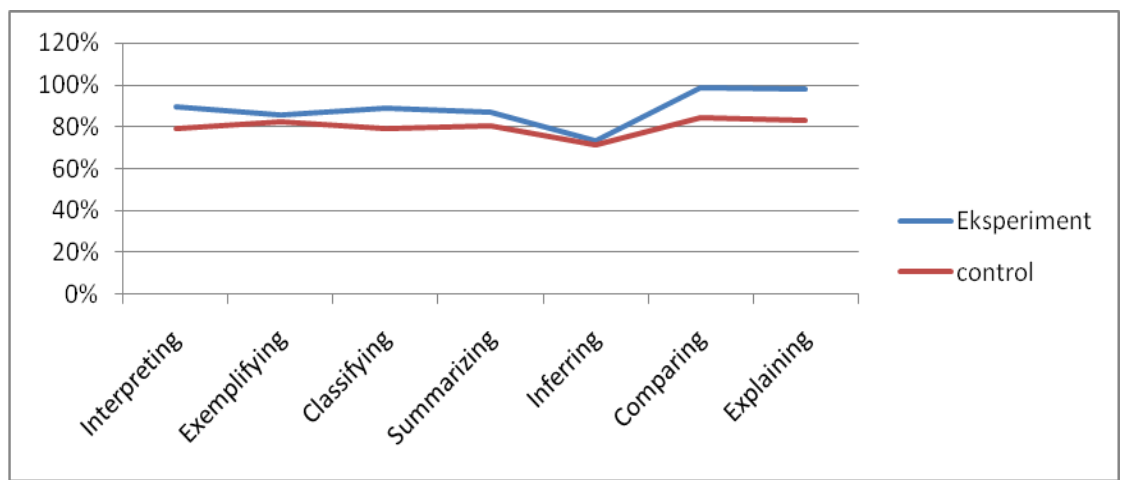

Figure 1. Percentage analysis of understanding the concept

The highest percentage of achievement lies in the compare indicator, since the cognitive comparison process occurs when the student is able to determine the relationship between two ideas, two objects, and the like. While the lowest percentage of achievement lies in the inferred indicator, because the cognitive process concludes the process of finding the pattern in a number example. Summing up occurs when the student can make a logical conclusion of the information received. On the item the question concludes most students have not been able to draw a logical conclusion.

Table 6. Analysis of science process skill indicators

\begin{tabular}{|c|c|c|c|c|c|c|c|c|}
\hline \multirow{2}{*}{ Model } & \multicolumn{8}{|c|}{ Indicator } \\
\hline & 1 & 2 & 3 & 4 & 5 & 6 & 7 & 8 \\
\hline $\begin{array}{l}\text { Scientific inquiry using } \\
\text { macromedia flash }\end{array}$ & $66,9 \%$ & $51,4 \%$ & $46,2 \%$ & $68,5 \%$ & $66,9 \%$ & $65 \%$ & $67 \%$ & $50 \%$ \\
\hline Conventional learning & $66,9 \%$ & $45,4 \%$ & $44,5 \%$ & $63,1 \%$ & $67,7 \%$ & $52 \%$ & $66,2 \%$ & $37,7 \%$ \\
\hline
\end{tabular}

In summary, the analysis of indicators of students' understanding of the concept of control class with conventional learning and experimental class with scientific inquiry model using macromedia flash can be seen in Figure 2.

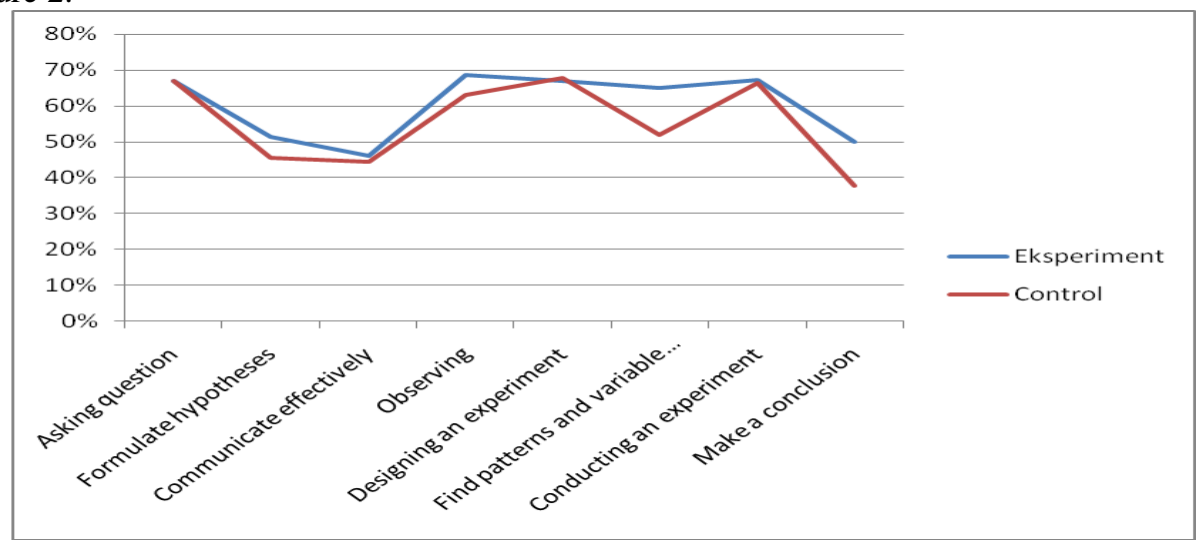

Figure 2. Percentage analysis of science process skill indicators

The highest percentage of achievement lies in observing indicators. Observation indicators are one of the basic process skills. The observational skill uses five senses, namely sight, smell, touch, taste and listener. When students gain the ability to observe by using multiple senses their awareness and sensitivity to everything around them will develop. Train student observation skills including train students to identify which senses are appropriately used to observe an object. While the lowest percentage of achievement lies in the indicators draw conclusions. Summing up is a fact-based statement of observations. The conclusion put forward as one's opinion. So students can not draw conclusions if they do not connect between concepts with what is obtained at the time of the lab.

\subsection{Discussion}

\section{Discussion and Conclusions}

4.1.1 Understanding the concept of students who taugh with scientific inquiry model using macromedia flash better than conventional learning 
Understanding the concept of students who are taught by scientific inquiry learning model using macromedia flash shows better results than learned by conventional learning. The result of supporting research is research of [18]; [19]; [20].

The cause of students' concept understanding in the experimental class is better than the control class is because scientific inquiry learning activities can support the students in solving the problems given by the teacher. Problems presented, answered by students through research activities or scientific work. Scientific work can facilitate students to acquire knowledge by using scientific methods ranging from mengobsevasi, formulate questions, create hypotheses, collect data and conclude. This activity will be able to improve students' concept comprehension ability. Understanding the concept of students is not obtained from the way of memorization. As delivered by [9] through inquiry learning can avoid students from learning by memorizing, as well as giving students time to assimilate and obtain information through research. Information obtained through research in the form of physics concepts as well as student decisions serve as a solution problem. The same thing is conveyed by [21] that inquiry learning provides an opportunity for students to have a real and active learning experience so that students are trained in solving problems as well as making decisions, and students can acquire concepts or materials they learn in various ways or forms for More understanding of the concepts or material being studied.

The second factor that leads to better understanding of student concepts in the experimental class than the control class is because students are trained to think logically. Logical thinking can be acquired by students when providing a logical argument to determine the conclusions of scientific work. The conclusion of scientific work will be the correct and correct concept when it is conveyed through a logical argument. Logical thinking can find a deeper understanding of students' concepts, as stated by [22] one of the skills closely related to student learning outcomes is the ability to think logically, ie the ability to find truth based on rules, Pattern or logic. This capability needs to be developed in the learning, as it can help the students to improve conceptual understanding. The ability to think logically can bridge on improving student learning outcomes through a correct understanding of concepts.

The third factor that leads to better understanding of student concepts in experimental class than control class is because in scientific inquiry learning students are trained to think systematically. Thinking systematic is the students follow the patterns of scientific methods, starting from the observation, students ask questions based on observations made. The formulation of questions posed by students will stimulate students' thinking ability in formulating the problem. In formulating the problem students will optimize their initial knowledge by recalling the concepts associated with the observation activities undertaken. As explained by [18] the initial knowledge that students have will have a positive impact on the students, that is the students will further strengthen the concepts in long-term memory.

In addition to these factors, the results of the analysis can also prove that learning will be more meaningful by using the simulation media because it can improve students' conceptual understanding. As explained by [23] in his research that the effectiveness of the use of computer simulation media can improve students' concept understanding and minimize misconception. The use of media simulation is necessary because there are some physics concepts that can not be seen directly eye. Simulations are designed to be similar to exercises, but not in actual reality, but rather seem to describe the true state in a limited sense. These simulations can be animations that can be used in the learning process because it helps teachers in the delivery of material, attract students' attention and as an alternative other learning models so that students are not saturated, it can mean that the animation media is very influential on the formation of student concepts during learning Media animation [24]. The simulation media will help the students in exploring the understanding of the concept of abstract physics material. The results of this study are supported by the results of [25] study that simulationbased inquiry learning is an effective way to promote students 'scientific ability and students' understanding of the subject of gas law.

In contrast to conventional learning in control classes, teachers tend to be more centered, meaning that in the learning process of teachers who play the most dominant role. The application of conventional learning, teachers present information step by step whereas students only pay attention and receive what has been delivered by the teacher. Teachers tell students what they should learn or read, thus causing the minds of students who do not develop well. Students are limited only considering the concepts of subject matter delivered by teachers but students do not understand for what the concept is learned, it can be said the concept of understanding has not been optimal.

4.1.2 The science process skills of the students' that is taught by scientific inquiry model using macromedia flash is better than conventional learning 
The skill of the students' science process which is taught by the scientific inquiry model using macromedia flash shows better result than students who are taught by conventional learning. The supporting results are [8]; [26]; [27].

The cause of the science process skills in the experimental class is better than the control class is because inquiry learning can involve students actively (student center) to investigate the problems presented on the student worksheet. According to [21] the inquiry process gives students the opportunity to have real and active learning experiences so that students are trained in solving problems while making decisions. Scientific inquiry learning activities can provide an opportunity for students to find something through experimentation. Facing students in a scientific activity (experiment), students are trained to be skilled in obtaining and processing information through thinking activities by following scientific (method) procedures, such as, skilled in observing, measuring, classifying, drawing conclusions and communicating the findings. As [28] points out that studying the process of scientific knowledge is a very important skill for students. This process is defined as a science-process skill that helps students build scientific learning and helps them become active participants in studying research techniques. Techniques of research trained in scientific inquiry learning can explore students' science process skills. According [29] that the skills of the process of science is the ability of students to apply scientific methods in understanding, developing and finding science. Scientific process skills are very important for every student as a provision to use scientific methods in developing science and is expected to acquire new knowledge or develop the knowledge already possessed.

The second factor that causes the students' science process skills in the experimental class is better than the control class is because the involvement of students in scientific inquiry learning provides experience and familiarizes the students with scientific work to develop the skills of the process of science in processing and finding the knowledge itself. According to [30] states the need for involvement of a process skill possessed by learners in learning activities, because process skill is a skill that scientists often use in solving problems that disturb their curiosity through laboratory activities. Learning in the experimental class with scientific inquiry teaching model gives students the opportunity to work to find science and not just listen and receive information only. The mode of presentation of the lesson, in which the student experiments with experiencing something himself learned. Teaching and learning with experimental methods provides an opportunity for students to experience themselves or do themselves, follow a process, observe an object, state or process something. Thus, students are required to experience themselves, seek the truth, or try to find a law or proposition, and draw conclusions. These processes are research techniques that can foster students' science process skills. Apart from these factors, the results of the analysis can prove that learning will be more effective when using instructional media. Learning using the media makes learning interesting and fun for students. Students can observe directly every process in the media. According to [31] that temperature and heat matter is one of the physics concepts that is difficult to explain if only using conventional methods, students consider this concept abstract and tend to be confused when they are faced with material that is considered abstract. This is what makes students feel difficult in learning physics. It is unlikely that students will have the right material and heat content if an abstract concept is only learned by the learning model. Such learning situations are suitable for computer simulations because students can observe a physical phenomenon and experiment with the computer simulations. Then the students explain the results of predictions and observations of the physical phenomena that have been shown in computer simulations.

As stated by [32], it can be concluded that one way to improve the mastery of science process and science concept for students is by using scientific inquiry instruction model by using interactive computer simulation.

Conclusions

Based on the results of research and discussion it can be concluded as follows:

1. Understanding the concept of students who dibelajarkan with scientific inquiry model using maromedia flash better than students who were taught by conventional learning.

2. Science process skills of students who are taught by scientific inquiry model using maromedia flash better than students who are taught by conventional learning

\section{References}

[1] Fraser, B. J. 2002. Chapter 1 Learning Environments Research: Yesterday, Today And Tomorrow. Curtin University of Technology, Australia.

[2] Anderson, O \& Krathwohl, D. 2010. Pembelajaran, Pengajaran dan Asesmen.Yogyakarta: Pustaka Pelajar.

[3] Sagala. 2011. Konsep dan Makna Pembelajaran. Bandung: IKAPI.

[4] Harlen, W \& Elstgeest, J. 1994. A workshop Approach to Teacher Education. Unesco: Printed in France.

[5] Mehmet, A.2012. Scientific Inquiry Based Professional Development Models in Teacher Education. Jurnal Pendidikan Fisika dan Aplikasinya (JPFA), 4(2): 42. 
[6] Ergul, Simsekli, Calis \& Gocmencelebi. 2011. The effects of Inquiry-Based Science Teaching On Elementary School Students Science Process Skills And Science Attitudes. Bulgarian Journal of Science and Education policy (BJSEP), 5(1):48-67.

[7] Njoroge. 2014. Effects of Inquiry Based Teaching Approach on Secondary School Students Achievement and Motivation in Physics in Country. Kenya. International Journal of Academic Research in Education and Review, 2(1): 1-6.

[8] Anggraini, D.P \& Sani, A.R. 2015. Analisis Model Pembelajaran Scientific Inquiry dan Kemampuan Berpikir Kreatif terhadap Keterampilan Proses Sains Siswa SMA. Jurusan Pendidikan Fisika Program Pasca Sarjana UNIMED. Jurnal Pendidikan Fisika, 4(2):47-54.

[9] Azeem, Hussain \& Shakoor. 2011. Physics Teaching Methods: Scientific Inquiry vs Traditional Lecture. International Journal of Humanities and Social Science, 1(19):269-276.

[10] Bukhori M.A.F. 2012. Pembelajaran Berbasis Inquiry untuk Optimalisasi Pemahaman Konsep Fisika pada Siswa di SMA Negeri 4 Magelang, Jawa Tengah. Berkala Fisika Indonesia, 4(1):11-12.

[11] Demirbag \& Gunel. 2014. Integreting Argument-Based Science Inquiry with Modal Representations. Impact on Science: Theory \& Practise. 14(1).

[12] Arsyad. 2008. Media Pembelajaran. Jakarta : Raja Grafindo Persada.

[13] Susilana \& Cevi. 2009. Media Pembelajaran: Hakikat Pengembangan, Pemanfaatan dan Penilaian, Bandung:CV. Wacana prima.

[14] Wahyuni \& Isa. 2012. Keefektifan Pembelajaran Berbantuan Multimedia Menggunakan Metode Inquiry untuk Meningkatkan Minat dan Pemahaman Siswa. Jurnal Pendidikan Fisika Indonesia, 6:58-62.

[15] Joyce, B., Well, M \& Calhoun, E. 2009. Model of Teaching (Model-Model Pengajaran) edisi kedelapan. Yogyakarta: Pustaka Pelajar.

[16] Fraenkel, J., Wallen, N., Helen \& Hyun. 2012. How to design and evaluate research in education 8th edition. McGraw-Hill, A Business Unit Of The McGraw-Hill Companies, Inc., 1221 Avenue of The Americas, New York, NY 10020. Copyright (C) 2012, 2009, 2006, 2003, 2000, 1996, 1993, 1990 By The McGraw-Hill Companies, Inc.

[17] Margono. 2009. Metodologi Peneltian Pendidikan. Jakarta: PT Rineka Cipta

[18] Anggareni, R \& Widiyani. 2013. Implementasi Strategi Pembelajaran Inquiry terhadap Kemampuan Berpikir Kritis dan Pemahaman Konsep Siswa SMP. e-journal Program Pascasarjana Universitas Pendidikan Ganesha, 3:1-11

[19] Dhakaa \& Amita. 2012. Biological Science Inquiry Model and Biology Teaching. Bookman International Journal of Accounts, Economics \& Business Management, 1(2):80-82.

[20] Simsek, P \& Kabapinar, F. 2010. The Effects of Inquiry-based Learning on Elementary Students's Conceptual Understanding of Matter, Scientific Process Skills and Science Attitudes. Procedia-Social and Behavioral Sciences, 2: 1190-1994.

[21] Rizal, M. 2014. Pengaruh Pembelajaran Inkuiri Terbimbing dengan Multi Representasi terhadap Keterampilan Proses Sains dan Penguasaan Konsep IPA Siswa SMP. Jurnal Pendidikan Sains, 2(3):159-165.

[22] Usdiyana, D., Tia, P., Kartika, Y., \& Eha, H. 2009. Meningkatkan Kemampuan Berpikir Logis Siswa SMP Melalui Pembelajaran Matematika Realistik: Jurnal Pengajaran MIPA, 13(1):1-14.

[23] Suhandi, A., Sinaga, P., Ida, K \& Endi, S. 2009. Efektivitas Penggunaan Media Simulasi Virtual pada Pendekatan Pembelajaran Konseptual Interaktif dalam Meningkatkan Pemahaman Konsep dan Meminimalkan Miskonsepsi: Jurnal Pengajaran MIPA,13( 1):1-13.

[24] Kusyanti, R. N. 2009. Pemahaman konsep Siswa setelah Menggunakan Media Pembelajaran Animasi Fisika. Seminar Nasional Penelitian, Pendidikan, dan Penerapan MIPA Fakultas MIPA, Universitas Negeri Yogyakarta, 89-95.

[25] Shariff, A \& Abdullah, S. 2008. The Effects of Inquiry-Based Computer Simulation with Cooperative Learning on Scientific Thinking and Conceptual Understanding of Gas Laws. University Sains Malaysia: Eurasia Journal of Mathematics, Science and Technology Education, 4(4):387-398.

[26] Ergin, O \& Aktamis, H. 2008. The Effect of Scientific Process Skill Education on Student's Scientific Creativity, Science Attitude and Academic Achievement. Asia-pasific Forum on Science Learning and Teaching, 9(1):1-21.

[27] Rauf1, Rose, Amnah, A., Mohamad, Sattar, R., Azlin,N., Mansor, Zarina, O., \& Lyndon. 2013. Inculcation of Science Process Skills in a Science Classroom. Malaysia. Asian Social Science,9(8):47-57.

[28] Delen. I \& Kesercioglu. T. 2012. How Middle School Students Science Process Skills Affected by Turkey's National Curriculum Change. Juornal of Science Education, 9(4):3-9.

[29] Hutagalung, A. M. 2013. Efek Model Pembelajaran Inquiry Training Berbasis Media Komputer terhadap Keterampilan Proses Sains dan Kemampuan Berpikir Kritis Siswa. Jurnal Pendidikan Fisika Pascasarjana Universitas Negeri Medan, 2(2):9-16.

[30] Udin, M., Arsyad \& Khaeruddin. 2013. Peningkatan Keterampilan Proses Sains melalui Model Pembelajaran Berdasarkan Masalah pada Siswa Kelas X SMA 14 Makassar. Jurnal Pendidikan Fisika, 1(2): 139-147.

[31] Hasanah, M, Ida, K \& Iyon, S. 2015. Pengembangan Simulasi Komputer Suhu dan Kalor Berbasis POE. Simposium Nasional Inovasi dan Pembelajaran Sains: 421-424

[32] Supriyatman \& Sukarno. 2014. Improving Science Process Skills (SPS) Science Conceps Mastery (SCM) Prospective Student Teachers Through Inquiry Learning Instruction Model by Using Interactive Computer Simulation: International Journal of Science and Research (IJSR), 3(2):6-9.

\footnotetext{
Rohana Hutahaean. "Effect Of Scientifi Inquiry Learning Models Usingmacromedia Flash On Understanding Concept And Skills Of The Science Process Principles Sma." IOSR Journal of Research \& Method in Education (IOSR-JRME) 7.4 (2017): 29-37.
} 